Tarih Kültür ve Sanat Araştırmaları Dergisi

Revue des Recherches en Histoire Culture et Art مجلة البحوث التاريخية والثقافية و الفنية
Vol. 7, No. 4, November 2018

Copyright (C) Karabuk University http://kutaksam.karabuk.edu.tr

\title{
DOI: 10.7596/taksad.v7i4.1840
}

Citation: Mukharlyamova, L., Konopleva, N., Galimzyanova, I., \& Berezhnaya, I. (2018). Formation of the Intercultural Communicative Competence of Students in Process of Learning Foreign Languages. Journal of History Culture and Art Research, 7(4), 230-236. doi:http://dx.doi.org/10.7596/taksad.v7i4.1840

\section{Formation of the Intercultural Communicative Competence of Students in Process of Learning Foreign Languages}

\author{
Liliya Mukharlyamova ${ }^{1}$, Natalya Konopleva ${ }^{2}$, \\ Ilkhamiya Galimzyanova ${ }^{3}$, Irina Berezhnaya4
}

\begin{abstract}
The article is devoted to the problem of formation of the intercultural communicative competence of students in process of learning foreign languages. The urgent problem of vocational education is the preparation of students for the use of a foreign language in communicative and professional activities, as well as the formation of intercultural communication. Along with professional and communicative skills, a graduate of a university should know the cultural and social characteristics of other nationalities. It allows them to orientate themselves in repetitive sociocultural situations, make a dialogue with representatives of foreign cultures, seek and find ways to resolve interethnic and interconfessional conflicts and have such qualities as tolerance, openness and willingness to communicate. Formation of intercultural communicative competence among students implies awareness of the native culture and other cultures, their interrelationships; ability and readiness for communication prevent conflicts that inevitably arise from such contacts; the ability to build new patterns of behavior, based on the values and norms of different cultures.
\end{abstract}

Keywords: Intercultural communicative competence, Foreign language, Foreign language culture, Professional activity, Intercultural dialogue.

\footnotetext{
${ }^{1}$ Associate professor, candidate of science, Leo Tolstoy Institute of Philology and Intercultural Communication, Kazan Federal University. E-mail: mukharlyamova@mail.ru

${ }^{2} \mathrm{PhD}$ in Philology, associate professor, Leo Tolstoy Institute of Philology and Intercultural Communication, Kazan Federal University. E-mail: Natalya.Konopleva@ksu.ru

${ }^{3}$ Doctor of Education, professor, Department of foreign languages and Intercultural Communication, Kazan State Conservatoire named after N. Zhiganov. E-mail: global@ores.su

4 Doctor of Education, professor, Department of pedagogy and pedagogical psychology, Voronezh State University. E-mail: mukharlyamova@mail.ru
} 


\section{INTRODUCTION}

Today, the professional activity of a modern specialist is not conceivable beyond communication training. Currently, due to the globalization and the possibility of communication and cooperation with foreign countries, many young professionals have the opportunity to work in various foreign professional groups, to pass master classes and internships in educational centers in Europe and America. In the context of new requirements to the quality of education, broadening of international relationships in all social and economical spheres as well as a need to increase the mobility of students and teaching staff, an important task to prepare students in foreign languages has become extremely important [1, pp.1295-1296]. "Globalization and migration of workforce have made it all the more important for the solution of current everyday problems, most of which arise because of inadequate communication strategies, crucial to the development of intercultural dialogue" [2, p.256]. The urgent problem of vocational education is the preparation of students for the use of a foreign language in communicative and professional activities, as well as the formation of intercultural communication.

"The modern requirements for the foreign language proficiency in high school include the presence of foreign language communicative competence of future specialists" [3, p.36]. At the present stage, along with professional and communicative skills, a graduate of a university should know the cultural and social characteristics of other nationalities. It allows them to orientate themselves in repetitive sociocultural situations, make a dialogue with representatives of foreign cultures, seek and find ways to resolve interethnic and interconfessional conflicts and have such qualities as tolerance, openness and willingness to communicate. Knowledge of his own and other peoples' cultural and spiritual values testifies to the general cultural level of the specialist.

Sometimes, because of the low level of intercultural competence, university graduates cannot adapt to the new community and they are unable to solve communicative and professional tasks. The specialist should have the desire to get knowledge all the time, the ability to master related specialties, as well as the acquisition of new professional knowledge throughout life. A foreign language plays a big role in it.

In this regard, in modern conditions, the main task of a foreign language teacher is to teach the language as a real means of communication between people of different cultures, i.e. "languages should be studied in indissoluble unity with the world and the culture of peoples speaking these languages" [4].

For successful foreign language teaching and the formation of students' intercultural competence, a teacher should possess both professional knowledge, namely, to master the language system, the teaching methodology, to know the culture of the countries of the studied language, its history and contemporary problems; and the art of communication, creating an open, friendly atmosphere of the educational process with establishing a strong feedback.

\section{RESULTS AND DISCUSSION}

Russia's accession to the Bologna Process has determined the new tendencies in the development of education and, as a consequence, the need to speak at least one foreign language at the level of international standards. The result of this process is the broad opportunities for communication between the bearers of a culture and representatives of other cultures, and these opportunities are now everyday reality for many countries and peoples. Such process of "interaction and mutual influence of cultures was called intercultural communication" [5].

E.M. Vereshchagin and V.G. Kostomarov, the founders of linguistic culture in Russia, gives the following interpretation of this concept: "intercultural communication presupposes an adequate mutual understanding of two participants in a communicative act belonging to different national cultures" [6]. 
O.A. Leontovich defines intercultural communication in general terms as "direct or indirect exchange of information by representatives of different linguistic cultures" [7]. For effective communication between representatives of different cultures, language skills are not enough. It is necessary to know the nationalspecific features of the communication culture components that can hinder the process of intercultural communication. Such components of cultures, according to researchers I. Yu. Markovina and Yu. A. Sorokina, can be:

a) Traditions, as well as customs and rituals;

b) Household culture, closely connected with traditions, as a result of which it is often called traditional and everyday culture;

c) Everyday behavior (habits of a certain culture representatives, accepted in some social norms of communication), as well as the associated mimic and pantomimic codes used by the bearers of some linguistic and cultural community;

d) "National world images", reflecting the specifics of the surrounding world perception, the national characteristics of a particular culture representatives' thinking;

e) An art culture reflecting the cultural traditions of an ethnos [8].

Thus, the main goal of any communication process is the maximum complete and accurate reporting of information, knowledge and experience to the partner of communication. The subject of research in the field of intercultural communication is the study of the national and cultural specifics of communicative behavior of participants in the communication process, the formation of certain practical skills, knowledge, which would make it possible to understand representatives of foreign cultures speaking foreign languages, in other words, the formation of intercultural competence.

In order to determine what skills an individual should have, O.A. Leontovich distinguishes "the three components of intercultural competence: linguistic, communicative and cultural" [7]. In the context of intercultural communication, "linguistic competence is directed towards the choice of linguistic means, which correspond to the situation of communication" [7]. Another factor, according to O.A. Leontovich, necessary for effective intercultural communication, is "cultural competence that provides an understanding of the background knowledge, values, psychological and social identity characteristic of the culture. The concept of cultural competence to a certain extent coincides with the concept of cultural literacy ..." [7]. For example, the distance in the conduct of a conversation is inseparably linked with the norms of accepting another person in their living space adopted in the given culture. Effective communication will not take place without a communicative component. According to D. Hymes, communicative competence with its components, such as "activity (the ability to direct the conversation in the right direction, the ability to clearly express one's thoughts and understand the idea of the interlocutor), relevance (choice of the topic of conversation, communication, verbal and non-verbal means); dynamism (empathy, flexibility in the choice of switching topics)" is of great importance for communicative activities [7]. Successful formation of communicative competence occurs constantly, at all stages of language training, due to a well thought-out system of special exercises aimed at acquiring knowledge and skills necessary for speech communication with native speakers.

The study of intercultural competence, belonging to the group of social and personal competencies, received coverage in the works of domestic scholars in several areas: the concept of dialogue of cultures in teaching a foreign language (V.V. Safonova, E.I. Passov); the fundamentals of intercultural and language communication (O.A. Leontovich, E.M. Vereshchagin, V.G. Kostomarov, A.P. Sadokhin, V.V. Kabakchi, S.P. Ter-Minasova); formation of the sociocultural competence of trainees (V.G. Vorobiev, A.V. Litvinov); 
formation of intercultural competence (I.A. Zimnyaya, V.P. Kolesov), intercultural competence in the process of professional training (I.L. Pluzhnik).

The practice of intercultural interaction shows that people cannot always achieve mutual understanding. This is due to various cultural traditions, norms of behavior, and standards adopted in their cultures. Therefore, due to the lack of understanding and acceptance of certain norms, there may be disagreements and even hostility towards each other, which indicates a low intercultural communicative competence (ICC).

Analysis of I.A. Zimnyaya's, I.L. Pluzhnik's, O.A. Leontovich's works, allows determining the structure of a foreign language ICC that contains the following components:

1. General culture (knowledge and possession of the general cultural system by values characteristic of different countries).

2. Linguistic culture (knowledge and possession of lexical and grammatical units of a foreign language, the ability to extract cultural and historical information).

3. Socio-cultural (knowledge of verbal and non-verbal means, observance of ethical and etiquette speech norms, knowledge of the national character, worldviews, psychology and mentality, tolerance as acceptance of the studied culture and a sense of respect for this culture).

4. Professional (knowledge of skills in the professional sphere, the ability to apply knowledge in a communication with a representative of another culture).

For greater effect, a cultural component was included in the study of foreign language. This is reflected in the fact that students gain knowledge of the language and culture of not only the country of the studied language but also their native country, as there is a tendency of people to consider and appreciate another culture from the perspective of the values and norms of their own culture. The shortage of interaction with native speakers of a foreign language using the texts with the cultural components is a good possibility of creating the missing language socio-cultural environment. They acquaint students with the culture, customs, and holidays (national, religious, traditional) in our country and the studied language; therefore, the curriculum includes such topics as "Traditions of Great Britain and Russia", "Traditional festivals of Great Britain and Russia". However, we should note that foreign books are not quite suitable for the formation of intercultural competence, because they don't provide the dialogue of cultures. Therefore, in parallel with the basic authentic educational complexes students use additional educational materials that reflect the cultural diversity of their native country, as well as the material, focused on future profession. They are also used cultural materials, including information on the life and work of prominent scientific and cultural figures of Russia, which play the role of source of information about national-cultural environment.

One of the important conditions for the formation of the ICC has spatial content of spaces, namely the audience, where classes are held - board; map of the target language and native country; pictures of attractions, for example, in London; the tables with grammar of the studied country's language; audio and video tape recorders; and the ability to use Internet resources. Systematic execution of listening tasks forms the specialist's necessary level of ICC for his adaptation to the conditions of intercultural communication; it develops creative intellectual activity and creativity, the ability of creative participation in intercultural communication.

Another important factor to improve ICC is the creative forms and methods of educational process organization, such as video tutorials, project work, learning situations, and organization of presentations that enhance oral communication and develop writing. 
It is very important to familiarize students with audio and video materials for the perception, understanding and further discussion to stimulate cognitive and communicative activity in learning a foreign language. Training complexes contain authentic information in a language that extends the understanding of the profession, cultural and linguistic diversity of the world. Completing tasks, the students acquire new linguistic knowledge, and form a comparative knowledge of the culture, traditions, customs, and achievements of their own nation and English-speaking peoples.

The project work on a foreign language covers the knowledge of different humanitarian subjects, such as music literature, the history of art culture, which allows considering this method and as an effective means of expanding the professional horizon through information obtained from foreign sources.

"Project technology is interaction in the course of training and learning in the system of social interaction, in which students take on not only individual, but also collective responsibility for solving collective tasks. It creates conditions that not only increase the volume of knowledge of future specialists, but also their mobility, creativity, and autonomy" [8].

Educational-speech situations "are defined as a set of speech conditions necessary for the student to correctly perform a speech action in accordance with the intended communicative task" [8]. Speech situation is made based on studied foreign texts or in the process of discussing certain topics that provide communicative motivation and relevance of speech activity. Educational and speech situations (the situation of a business meeting with a native speaker, or the situation of staying in a foreign country, etc.) contribute to the modeling of "live speech" and the establishment of contacts with the native speaker.

Along with the traditional types of work, the professional skills of the future specialist are formed analytical reading the texts on the specialty, participation in discussions, writing abstracts, a public presentation with a report. This creates a problematic situation, which activates thinking and serves to generate speech. In addition, extracurricular activities (collection of material for wall newspapers, parties, students scientific-practical conference in a foreign language) give an opportunity to express themselves, help to develop a value attitude to language as parts of culture, increase the interest of students in the study of foreign languages.

Formation of intercultural communicative competence among students implies awareness of the native culture and other cultures, their interrelationships; ability and readiness for communication prevent conflicts that inevitably arise from such contacts; the ability to build new patterns of behavior, based on the values and norms of different cultures. It assumes the development of such personal qualities as patience, the ability to empathy, and tolerance.

Thus, the combination of both traditional and non-traditional methods of teaching a foreign language helps to create, support and develop the ICC and educate future professionals with such qualities as tolerance, openness, respecting the culture and spiritual values of one's own and other peoples capable and willing to participate in the dialogue of cultures. Awareness of the specifics of different spheres of life of native speakers, their own values and ways of behavior, as well as their impact on the use of language, can be considered an indicator of the formation of students to communicate in a foreign language in the course of intercultural communication.

\section{CONCLUSIONS}

The orientation of the educational process on the competent content of education assumes the formation not only of communicative competence, but also of competences related to life in a multipolar world, designed to prevent the emergence of misunderstanding, alienation and spread of xenophobia. 
Formation of the students' ability of foreign ICC is carried out in the process of teaching all types of speech activity (reading, speaking, writing, and listening) both in the course of classroom activities and in the course of out-of-class work. The main goal is to prepare students for the use of a foreign language in professional and scientific activities, which involves equipping students with the necessary minimum professional vocabulary, knowledge of the basics of professional activities related to the use of a foreign language, and the basis of ICC.

\section{ACKNOWLEDGEMENTS}

The work is performed according to the Russian Government Program of Competitive Growth of Kazan Federal University.

\section{FOOTNOTES}

1. Akhmadullina, R. M., Abdrafikova, A. R., \& Vanyukhina, N. V. (2016). The use of music as a way of formation of communicative skills of students in teaching English language. International Journal of Environmental and Science Education, 11(6), 1295-1302.

2. Mukhametzyanova, L., \& Svirina, L. (2016). Intercultural Citizenship and English Classroom Language. Journal of Organizational Culture, Communications and Conflict, 20, Special Issue, 256-262.

3. Fahrutdinova, R. A., Yarmakeev, I. E., \& Fakhrutdinov, R. R. (2014). The Formation of Students' Foreign Language Communicative Competence during the Learning Process of the English Language through Interactive Learning Technologies (The Study on the Basis of Kazan Federal University). English Language Teaching, 7(12), 36-46.

4. Ter-Minasova, S. (2000). Language and Intercultural communication. Moscow: Slovo.

5. Iriskhanova, K. M. (eds.) (2005). Pan-European competencies in foreign language proficiency: study, teaching, assessment under the editorship of the Ministry of Foreign Affairs. MSLU.

6. Vereshchagin, E. M., \& Kostomarov, V. G. (1990). Language and culture. Moscow.

7. Leontovich, O. A. (2000). Russia and USA: introduction in intercultural communication. Volgograd: Peremena.

8. Narolina, V. I. (2009). Preparation of a specialist for intercultural competence. Higher Education in Russia, 1, 124-128.

9. Bhawuk, D. P. S., \& Brislin, R. W. (2000). Cross-Cultural Training: A Review. Applied Psychology: an international review, 49, 162-191.

10. Shayakhmetova, L., Shayakhmetova, L., Ashrapova, A., \& Zhuravleva, Y. (2017). Using Songs in Developing Intercultural Competence. Journal of History Culture and Art Research, 6(4), 639-646. DOI: http://dx.doi.org/10.7596/taksad.v6i4.1157

\section{REFERENCES}

Akhmadullina, R. M.; Abdrafikova, A. R. \& Vanyukhina, N. V. (2016). The use of music as a way of formation of communicative skills of students in teaching English language. International Journal of Environmental and Science Education, 11(6), 1295-1302. 
Bhawuk, D. P. S. \& Brislin, R. W. (2000). Cross-Cultural Training: A Review. Applied Psychology: an international review, 49, 162-191.

Fahrutdinova, R. A.; Yarmakeev, I. E. \& Fakhrutdinov, R. R. (2014). The Formation of Students' Foreign Language Communicative Competence during the Learning Process of the English Language through Interactive Learning Technologies (The Study on the Basis of Kazan Federal University). English Language Teaching, 7(12), 36-46.

Iriskhanova, K. M. (eds.) (2005). Pan-European competencies in foreign language proficiency: study, teaching, assessment under the editorship of the Ministry of Foreign Affairs. MSLU.

Leontovich, O. A. (2000). Russia and USA: introduction in intercultural communication. Volgograd: Peremena.

Mukhametzyanova, L. \& Svirina, L. (2016). Intercultural Citizenship and English Classroom Language. Journal of Organizational Culture, Communications and Conflict, 20, Special Issue, 256-262.

Narolina, V. I. (2009). Preparation of a specialist for intercultural competence. Higher Education in Russia, 1, 124-128.

Shayakhmetova, L.; Shayakhmetova, L.; Ashrapova, A. \& Zhuravleva, Y. (2017). Using Songs in Developing Intercultural Competence. Journal of History Culture and Art Research, 6(4), 639-646. DOI: http://dx.doi.org/10.7596/taksad.v6i4.1157

Ter-Minasova, S. (2000). Language and Intercultural communication. Moscow: Slovo.

Vereshchagin, E. M. \& Kostomarov, V. G. (1990). Language and culture. Moscow. 